\title{
UseDa - A new database tool on ethnobotanical uses of West African plant species
}

\author{
Karen Hahn ${ }^{1,3}$, Marco Schmidt ${ }^{2,3}$, Anne Mette Lykke ${ }^{4}$, Adjima Thiombiano \\ 1 J. W. Goethe University, Institute for Ecology, Evolution and Diversity, Max-von-Laue-Str. 13 B, 60438 Frankfurt am \\ Main, Germany \\ 2 Senckenberg Research Institute, Department of Botany and molecular Evolution, Senckenberganlage 25, 60325 Frankfurt \\ am Main, Germany \\ 3 Biodiversity and Climate Research Centre (BiK-F), Senckenberganlage 25, 60325 Frankfurt am Main, Germany \\ 4 Aarhus University, AU Research and Talent, Helsingforsgade 27, DK-8200 Aarhus N, Denmark \\ 5 University of Ouagadougou, Laboratory of Plants Biology and Ecology, 03 BP 7021 Ouagadougou, Burkina Faso
}

\begin{abstract}
Summary: Knowledge about useful plants and their various applications in West Africa is scattered over many publications and often in form of grey literature difficult to access. Several online-databases compile large scale information from these sources and provide comprehensive summarized descriptions of plant usages. Our aim is to additionally build up a database (UseDa) for primary ethnobotanical interview data. Thus, quantitative data can be extracted and synthesized and data sets can be treated according to different research questions analyzing for example uses in specific areas, of different ethnic groups or user groups, which is essential for practical applications on a local level. In this article we give an overview on the technical structure and the content of the database and discuss at the end the possible output for practical application. The database was set up in the frame of the EU-funded Project UNDESERT.
\end{abstract}

Key words: Ethnobotany, data base tool, West African plants.

\section{USEDA - UN NOUVEL OUTIL DE BASE DE DONNÉES SUR LES UTILISATIONS ETHNOBOTANIQUES DES PLANTES DE L'AFRIQUE DE L'OUEST}

Résumé : La connaissance sur les plantes utiles et leurs diverses applications en Afrique de l'Ouest sont dispersées sur de nombreuses publications et souvent difficiles d'accès car souvent publiées sous la forme de littérature grise. Plusieurs bases de données en ligne compilent à grande échelle des informations provenant de ces sources et fournissent des descriptions synthétiques des usages des plantes. Notre objectif est de construire une base de données (UseDa) pour les données primaires des enquêtes ethnobotaniques. Ainsi, les données quantitatives peuvent être extraite et synthétisée et elles peuvent être traitées selon différentes questions de recherche analysant par exemple leurs utilisations dans des zones spécifiques, par différents groupes ethniques ou groupes d'utilisateurs, ce qui est essentiel pour les applications pratiques au niveau local. Dans cet article, nous donnons un aperçu sur la structure technique et le contenu de la base de données et discutons à la fin les options possibles pour une application pratique. La base de données a été mise en place dans le cadre du projet UNDESERT financé par l'UE.

Mots clés: Ethnobotanique, outil de base de données, plantes Ouest-Africaines.

\section{USEDA - EIN NEUES DATENBANK-INSTRUMENT ZUR ETHNOBOtANISChEN NUTZUNG VON WESTAFRIKA- NISCHEN PFLANZEN}

Zusammenfassung: Das Wissen über die Nutzung von Wildpflanzen in Westafrika und ihre verschiedenen Anwendungen ist in zahlreichen, breit gestreuten Publikationen dokumentiert und oft in Form von grauer Literatur schwer zugänglich. Mehrere Online-Datenbanken umfassen Informationen aus diesen Quellen und bieten zusammenfassende Kurzbeschreibungen der Pflanzen Nutzungen. Unser Ziel ist es, zusätzlich eine Datenbank (UseDa) für ethnobotanische Primärdaten aus Interviews aufzubauen. Damit können quantitative Daten extrahiert und synthetisiert werden. Es können Datensätze nach verschiedenen Fragestellungen analysiert werden, z.B. der Frage nach verwendeten Arten in bestimmten Gebieten, durch verschiedene ethnische Gruppen oder unterschiedliche Nutzergruppen, was für die praktische Anwendung auf lokaler Ebene von Bedeutung ist. In diesem Artikel geben wir einen Überblick über den technischen Aufbau und den Inhalt der Datenbank und diskutieren am Ende den möglichen Output für die praktische Anwendung. Die Datenbank wurde im Rahmen des EU-geförderten Projekt UNDESERT aufgebaut.

Schlagworte: Ethnobotanik, Datenbank, westafrikanische Pflanzen. 


\section{INTRODUCTION}

Many cash poor rural communities in West Africa strongly depend on the provisioning ecosystem services of their environments, that is products directly obtained from the ecosystems, e.g. food, fibers, medicine (CAPISTRANO et al. 2005). Particularly non-timber forest products (NTFPs), which comprise any products other than timber derived from forests and woodlands (e.g. fruits, leaves, bark, roots), contribute significantly to maintain livelihoods (LYKKE et al. 2004 , PARÉ et al. 2010, Heubach et al. 2011). A wide range of plant species are used mainly for households' subsistence and consumption needs, whereas some tree species also provide regular cash income (Heubach et al. 2011, Heubes et al. 2012), as their products are sold on local markets (e.g. soulbala, a condiment made from seeds from Parkia biglobosa) are even exported (e.g. shea nuts of Vitellaria paradoxa).

For a number of plant species, general information about their use for different purposes (e.g. medicine, consumption, energy and construction) is available (BuRKILL 1995, Arbonnier 2002, Thiombiano, Schmidt et al. 2012). However, recent studies in West Africa showed that use values of plant species can differ considerably due to social and spatial differentiations, e.g. age, gender, ethnic affiliation, village (Kepe 2008, De Caluwé et al. 2009, Schumann et al. 2012, Sop et al. 2012). Subsequently detailed data are required to assess species use values according to different user groups as well as different areas with varying availabilities of species. Extensive knowledge on local use preferences and the socio-economic values of species therefore is important for the development of sound practical actions and appropriate conservation strategies towards sustainable use for maintaining species populations or for increasing and improving degraded populations through planting measures. In this regard it is also important to assess and collect information on the population status and developing trends of useful species.

Knowledge about useful plants and their various applications in West Africa is still scattered over many publications and quite often in form of grey literature difficult to access. In recent years several initiatives came up to create online databases for making access easier to data on useful plant species, e.g. SEPASAL (the Survey of Economic Plants for Arid and Semi-Arid Lands) or PROTA (Plant Resources of Tropical Africa). These databases compile on large scale information from different ethnobotanical literature sources and make the description of plant usages available through the web (http://www.kew.org/ceb/sepasal/index.html, http:// database.prota.org/) or synthesis publications (PROTA 2010). As these data are synthesized, however, neither sitespecific data nor data related to ethnic groups or quantitative data are available from these sources.

With the construction of the database UseDa we aim at collecting and compiling primary interview data, which enable researchers to synthesize and extract quantitative data. Thus, different data sets can be treated according to different stakeholder interests, e.g. for different areas, ethnic groups, user groups (women, men, pastoralists, farmers), which is essential for practical applications.

The database UseDa was developed in the frame of the EUfunded research project UNDESERT: "Understanding and combating desertification to mitigate its impact on ecosystem services" (www.undesert.neri.dk). Data are continuously entered by scientists from several West African and European countries (Benin, Burkina Faso, Denmark, Germany, Niger, Senegal) collaborating closely in UNDESERT. In the following we describe the technical structure and the content of the database.

\section{TECHNICAL STRUCTURE OF THE DATABASE}

The user interface of the database is designed in Delphi. The data storage takes place in MS Access and queries and reports are carried out in MS Access. The database management system MS Access was chosen as it is available to many people as part of the MS Office suite. Each user can create his own local database to store the data. At a given time these local databases can be exchanged between researchers and/or joined in a central database as all records are unambiguously identified by GUIDs (globally unique identifiers). UseDa's plant names are following the AFRICAN Plants Database (2012) as a standard list and can therefore be easily linked to other botanical resources for West Africa using the same standard, including the West African Vegetation Database (SchMiDT et al. 2012) and 'African Plants - a photo guide (DrESSLER et al. 2014). This makes it possible to include information on co-occurrence, community structure, a range of plant trait data and geographical distributions in joint analyses with plant use data.

\section{Content of the database}

To set up the database entry mask we considered two types of interviews for gathering most important information on use values and the status of species: i) structured general interviews which serve to gather broad information from several study areas on multipurpose woody species, ii) a structured detailed interviews, which assesses more detailed information for single species use.

Structured general interviews serve to assess broader information on the general usefulness and use preferences of local stakeholders as well as their perception of the population status of the species. The knowledge and perception of local resource users provide valuable insights into the local vegetation and its development (CunNINGHAm 2001) and is thus one of the most important sources for indications on species population changes as historical and long-term data generally are lacking in West Africa. Moreover information about the planting interests of local communities is part of these interviews. The questionnaires consider a large number of woody species, which are important due to their multipurpose use function. The species are selected on the basis of expert knowledge of the study areas and literature. Besides general information on the interviewed person the questionnaires comprise the following fields: 
- use preferences $(0=$ not useful, $1=$ a bit useful, $2=$ useful, 3 = very useful)

- abundance of species $(0=$ no, $1=$ rare, $2=$ medium, $3=$ common)

- change of species $(0=$ unchanged, $1=$ a bit increasing, $2=$ very increasing, $-1=$ somehow declining, $-2=$ very declining)

- planting interest $(0=$ not useful, $1=$ a bit useful, $2=$ useful, 3 = very useful)

Structured detailed interviews

This type of interview contains questions concerning more detailed information on the use value of species. Besides the general information on the interviewed person we assess information on

- use and use value of species for different purposes (e.g. fire wood, consumption, medicine, construction, pasture)

- plant parts used

- used quantities

- harvesting practices

- local conservation practices

- species abundances and their development

- economic value (e.g. sale on markets)
The different types of interviews generate data with different information depth and content. The different data sets can be treated either individually or in combination for extracting relevant information on the value of species according to stakeholder specific interests on different spatial scales (e.g. most important species for planting interests in a specific study area, most important cash providing species for women in a specific study area, highly ranked species which are decreasing and for which people show planting interests in several study areas).

According to these types of interviews the entry mask of the database was constructed. It is organized in several parts (see screen shots below). The first part contains fields for general information on the interview event (interviewer, interviewed person, location, etc.), species-specific information (scientific name, local names, voucher specimens), the use of different plant parts, the use value and commercial value, the harvesting areas, harvesting periods and frequencies, and other species related information (local conservation strategies, planting interests, local perception of species abundances and development). Data from structured general interviews and structured detailed interviews can be integrated. Free text fields were inserted to allow for additional information of various kinds (e.g. calculated economic value of a species product). Secure long term archiving of such data can be provided by integration into the MetaCat system.

The main page of UseDa (Fig. 1) gives an overview on the interviews in the database. Interviews can be selected accor-

\begin{tabular}{|c|c|c|c|c|c|c|c|c|c|c|c|}
\hline \multicolumn{5}{|c|}{78 UseDa 1.2 - Karen Hahn - Admin } & \multicolumn{6}{|c|}{ 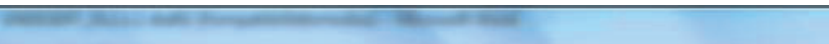 } & \multirow[t]{2}{*}{ E回 $x$} \\
\hline \multicolumn{11}{|c|}{ Exit Tools } & \\
\hline \multicolumn{2}{|c|}{ English $=$} & \multicolumn{2}{|c|}{ 帨 Create new Interview } & X Delete selected Interview... & iew... & \multicolumn{2}{|c|}{ Q Sesch for Interview-1D } & & \multicolumn{2}{|l|}{ Export to Excel } & \\
\hline Detals & Interview-ID & Date & Created by & Interviewer & Country & Region & Departement & Village & Interviewed Person & Species & \\
\hline$\ldots$ & 11 & $10 / 4 / 2011$ & Karen Hahn & Katja Heubach & Benin & Atacora & Boukoumbe & Papatia & MF1 & 5 Species $\ldots$ & \\
\hline$\ldots$ & 4 & $8 / 12 / 2011$ & Karen Hahn & Daniela Haarmeyer & Burkina Faso & Gourma & Comin-Yanga & Kikideni & PT1 & 8 Species $\ldots$ & \\
\hline \begin{tabular}{|c|}
$\ldots$ \\
\end{tabular} & 6 & $8 / 12 / 2011$ & Karen Hahn & Daniela Harmeyer & Burkina Faso & Gourma & Comin-Yanga & Kikideni & AT1 & 8 Species $\ldots$ & \\
\hline \begin{tabular}{|c|}
$\ldots$ \\
\end{tabular} & 8 & $8 / 12 / 2011$ & Karen Hahn & Daniela Haarmeyer & Burkina Faso & Gourma & Comin-Yanga & Fada N'Gourma & AT2 & 7 Species $\ldots$ & \\
\hline$\ldots$ & 5 & $8 / 12 / 2011$ & Karen Hahn & Daniela Haarmeyer & Burkina Faso & Gourma & Comin-Yanga & Kikideni & YL1 & 9 Species .... & \\
\hline$\ldots$ & 7 & $8 / 12 / 2011$ & Karen Hahn & Daniela Haarmeyer & Burkina Faso & Gourma & Comin-Yanga & Comin-Yanga & AT3 & 9 Species $\ldots$ & \\
\hline$\ldots$ & 3 & $8 / 12 / 2011$ & Karen Hahn & Daniela Haarmeyer & Burkina Faso & Gourma & Comin-Yanga & Kikideni & ML1 & 6 Species $\ldots$ & \\
\hline$\ldots$ & 13 & $4 / 10 / 2011$ & Karen Hahn & Katja Heubach & Benin & Atacora & Boukoumbe & Papatia & TB1 & 6 Species $\ldots$ & \\
\hline$\ldots$ & 17 & $4 / 10 / 2011$ & Karen Hahn & Katja Heubach & Benin & Atacora & Boukoumbe & Papatia & ST1 & 9 Species $\ldots$ & \\
\hline \multicolumn{2}{|c|}{ User: } & \pm & Country: & 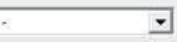 & Region: & & $\exists$ & patement: -all- & $\exists$ & Village: & $\exists$ \\
\hline
\end{tabular}

Fig. 1: Start page of the database with an overview on entered data/ La page de démarrage de la base de données avec un aperçu sur les données saisies.

ding to the user and the location (country, region, department etc.).

In the 'General' entry mask of an interview (Fig. 2) information on the interviewer and detailed information on the locality of the interviewed person (in an anonymized form) can be inserted. Entries for the country, the region and the department can be chosen out of lists; the geographical coordinates can be inserted directly in decimal degrees or in degrees, minutes, seconds and will then be transformed automatically in decimal degrees. Information on the interviewed person contains fields for the coded name, the profession, age, sex, the ethnic group, religion and the family status.

The 'Species' entry mask (Fig.3) provides fields to choose the species in the taxon list (integrated from the Vegetati- on database VegDa), the family name is then automatically completed and local names can be inserted in different local languages.

In the 'Use Value' entry mask (Fig. 4) main usages can be inserted, divided into sub usages, the use value, the used plant parts for the different use purposes, the harvesting areas and harvesting periods and frequencies as well as broad information about the commercial value.

The 'Species other' entry mask (Fig. 5) provides fields for information on existing conservation strategies and the perception about species frequency, the population development and the reasons and causes for this development. Furthermore data on planting interests can be inserted. 


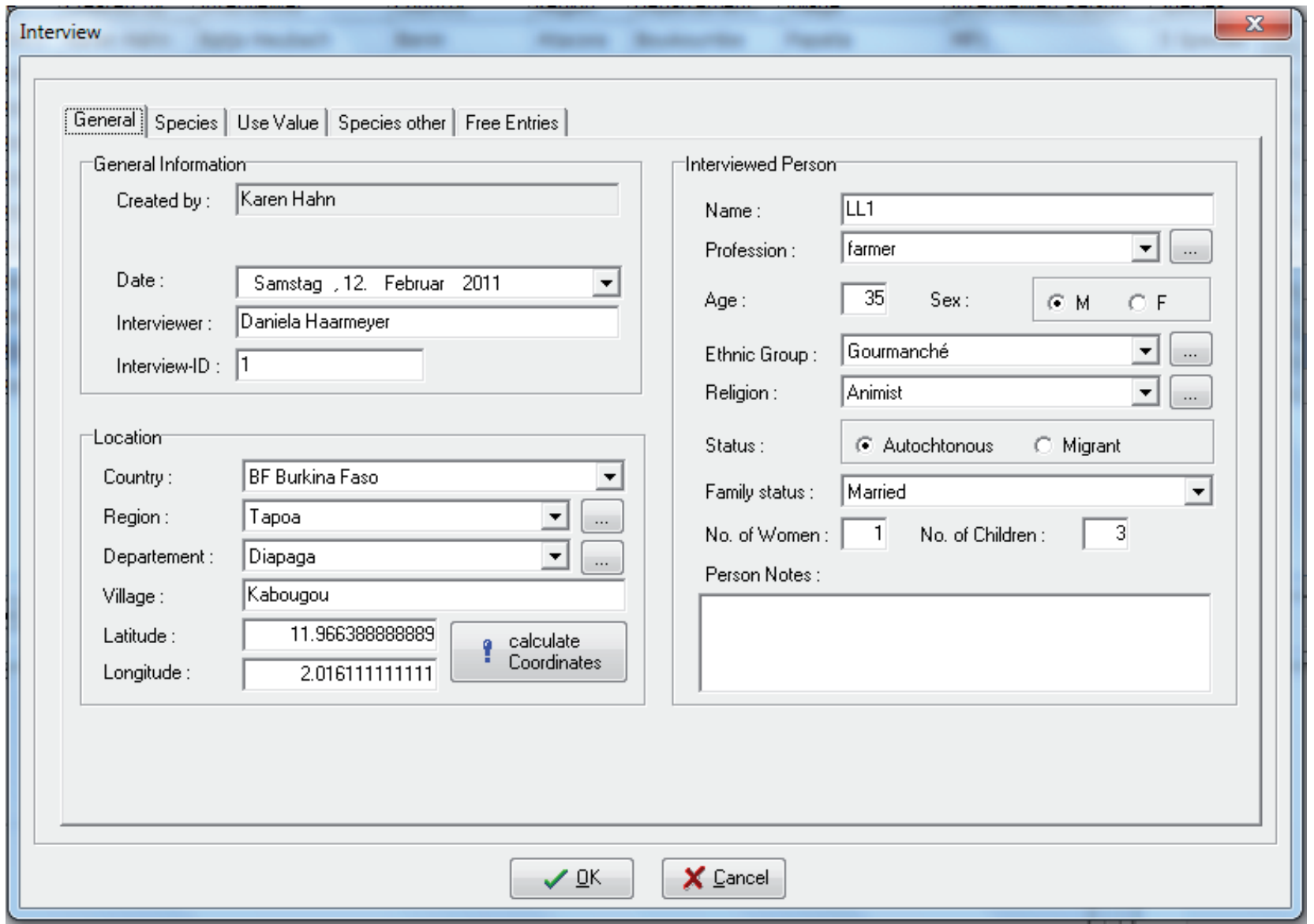

Fig. 2: Entry mask for general information of the interview / Masque de saisie pour des informations générales d'une enquête.

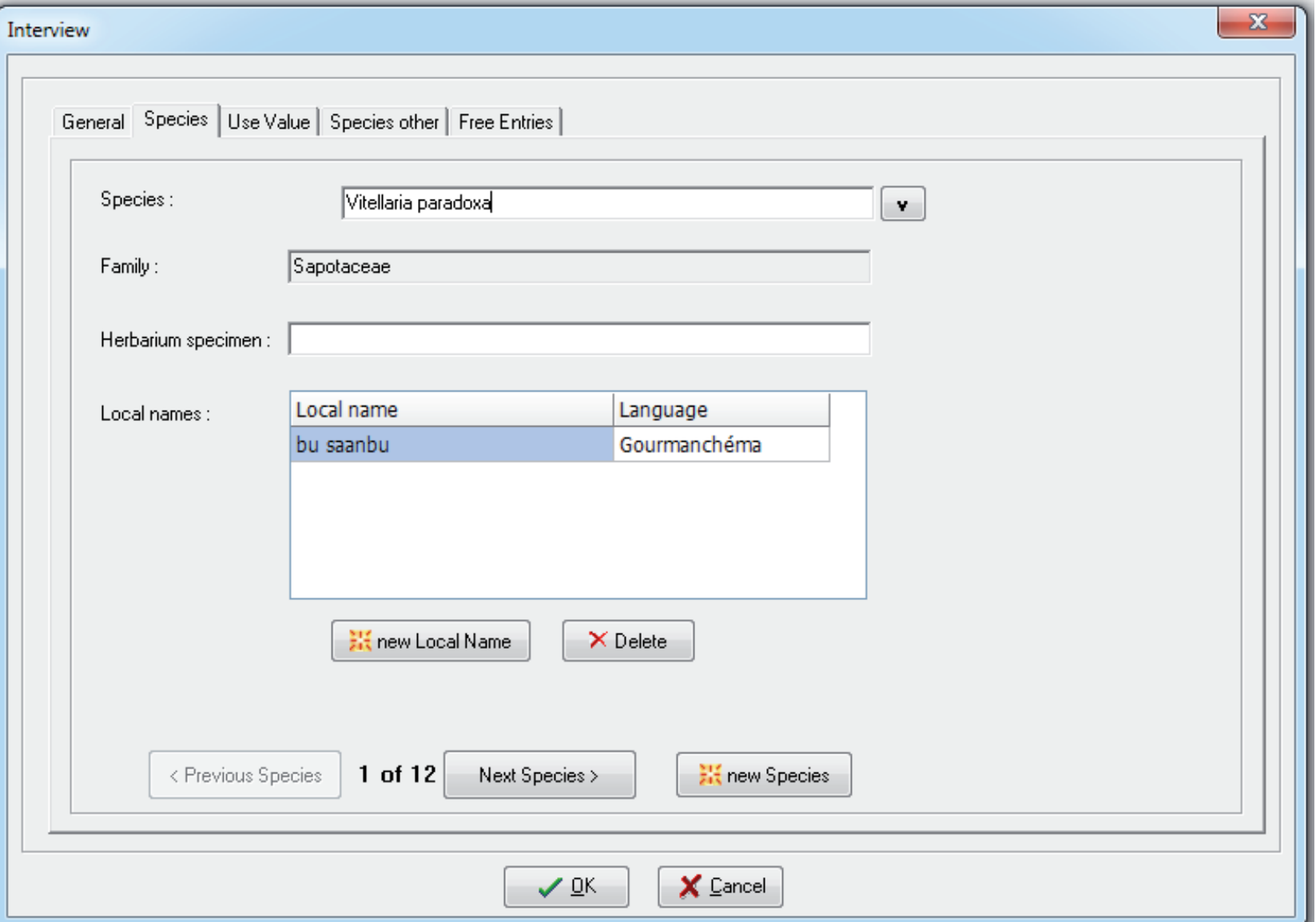

Fig. 3: Entry mask for information on the species/ Masque de saisie des informations sur les espèces. 


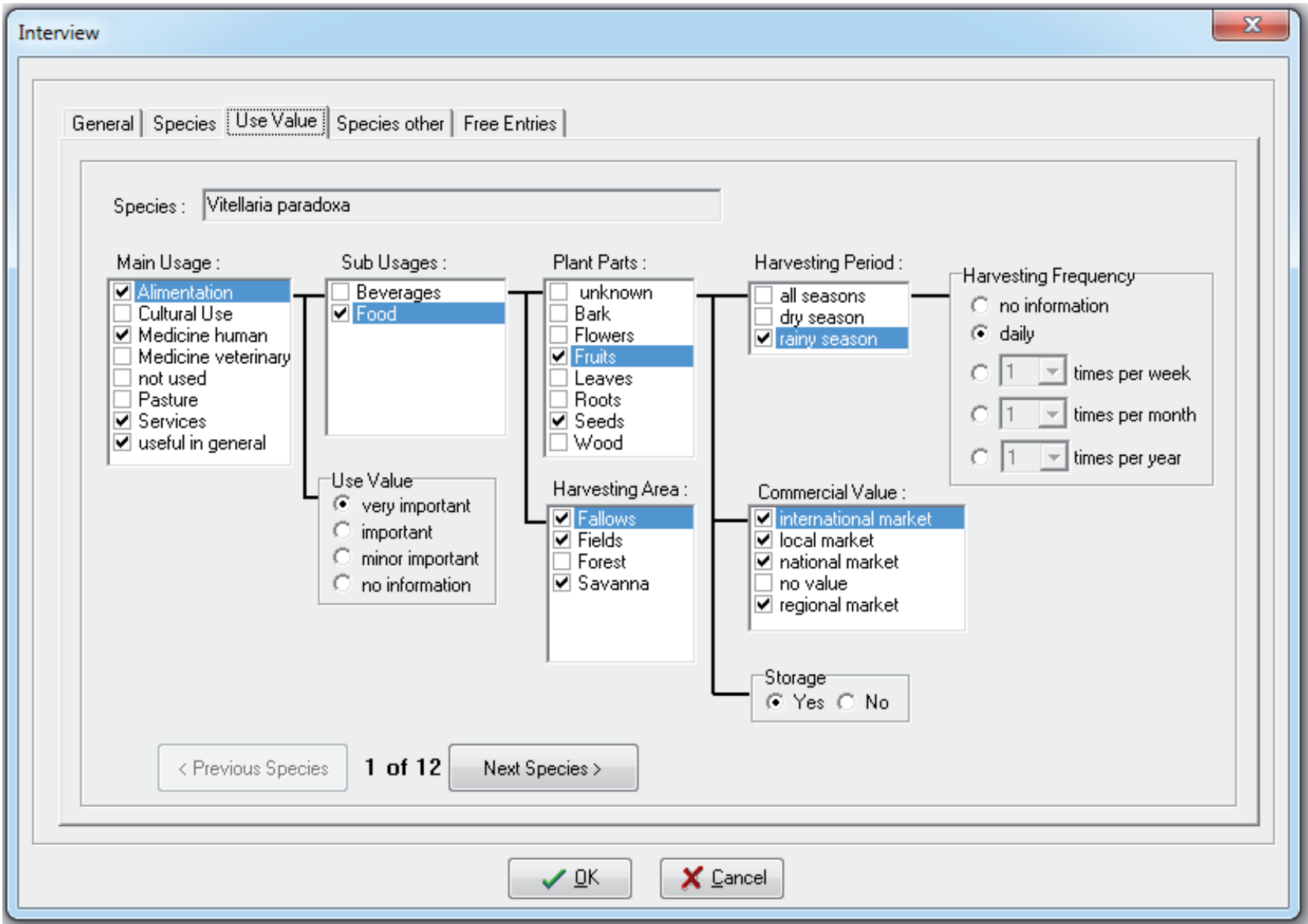

Fig. 4: Entry mask for use value information / Masque de saisie des informations sur la valeur d'usage.

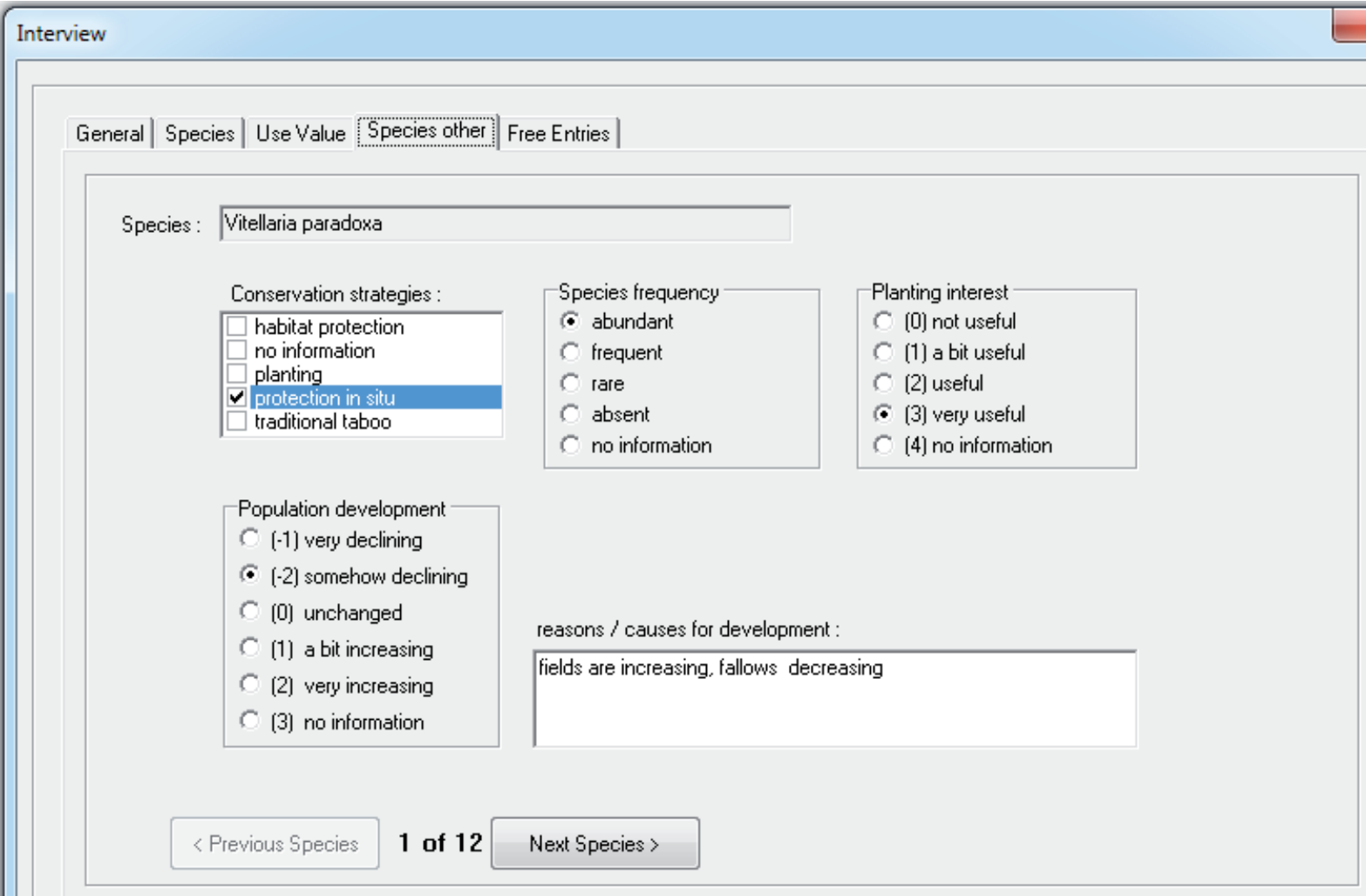

Fig. 5: Entry mask for other information on species / Masque de saisie pour d'autres informations sur les espèces. 
The 'Free Entries' entry mask (Fig. 6) provides text fields for more descriptive information on the species use. The text fields are coded according to the category fields in the first column for easier extraction and export into Excel files.

For the export of data into Excel-files different options can be chosen (Fig. 7)
Export of

- all data in one file

- data from the general interview type

- data on the use of different plant species

In addition each user can create its own queries in MS Access according to specific interests.

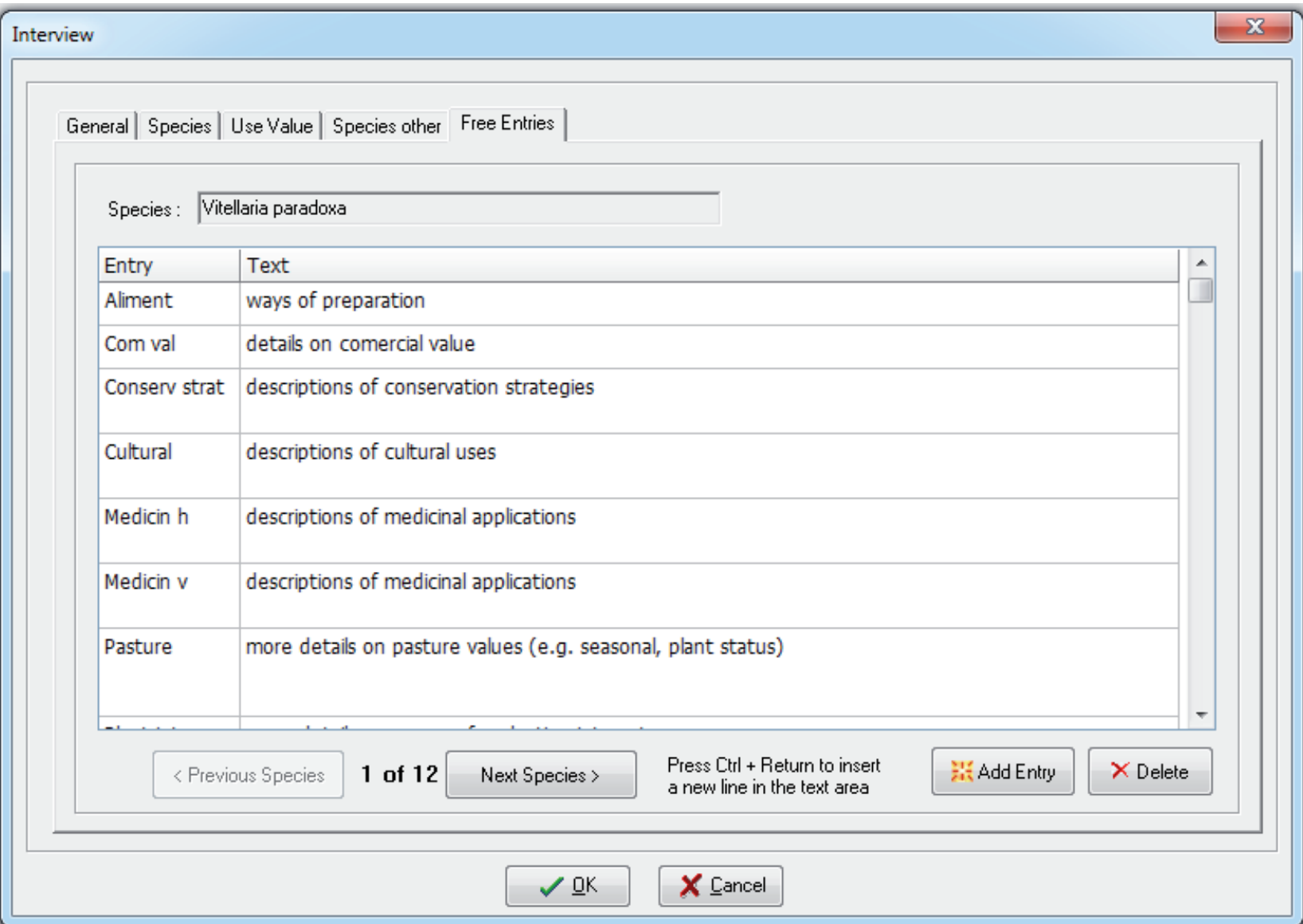

Fig. 6: Entry mask for free entries (text fields) for different categories / Masque de saisie pour entrées libre (texte) pour les différentes catégories.

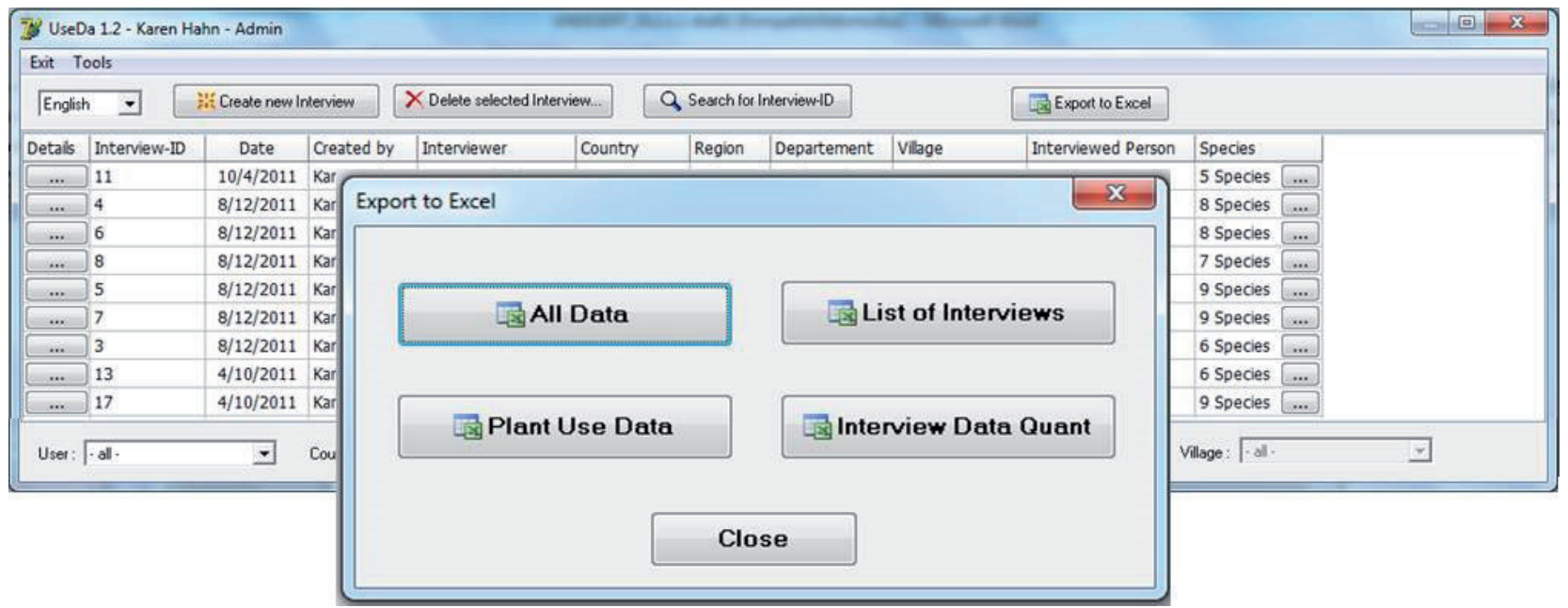

Fig. 7: Export function for data extraction into Excel files / Fonction d'exportation pour l'extraction de données dans des fichiers Excel. 


\section{THE OUTPUT FOR PRACTICAL APPLICATION}

UseDa output data provide information on a wide scale ranging from broad overviews down to very detailed knowledge according to different stakeholder interests for practical application. It is for example possible to obtain quantitative data on species which have a high use value i) in all investigated areas, ii) per specific area, iii) for different ethnic groups or iv) for certain user groups. We can also provide information about the user specific interests and differences between users that is preferences of men, women, and younger generation, as it is highly important to consider specific interests of distinct groups in the planning of measures for sustainable use of the species. Moreover species which are of specific interest for planting and income generation (market values) can be identified according to different areas, users etc.. It will also possible to compare species use and species status for species that are declining in numbers in order to identify areas with sustainable practices, which can be promoted as 'best practices' to other areas with unsustainable practices. Thus with this database we provide detailed quantitative information on highly important species which is essential for further measures of sustainable use of the species for long term income generation. This information will be combined with ecological knowledge such as distribution and habitat preferences of the species, which are compiled in the West African vegetation database (SCHMIDT et al 2012).

\section{ACKNOWLEDGEMENTS}

We acknowledge funding by the UNDESERT project "Understanding and combating desertification to mitigate its impact on ecosystem services" (EU FP7: 243906), which is funded by the European Commission, Directorate General for Research and Innovation, Environment Programme. Additionally, we acknowledge funding by the Biodiversity and Climate Research Center (BiK-F), part of the LOEWE program of the state of Hesse.

\section{REFERENCES}

African Plants Database (version 3.4.0), (2012). Conservatoire et Jardin botaniques de la Ville de Genève and South African National Biodiversity Institute, Pretoria, Retrieved 2012 from <http://www.ville-ge.ch/musinfo/bd/cjb/africa/>.

ArbonNiER M (2009): Arbres, arbustes et lianes des zones sèches d'Afrique de l'Ouest.

BuRKILl HM (1995): The useful plants of West tropical Africa, Vols. 1-3, pp. 976; 648; 868.

Capistrano D, Samper C, Lee MJ, Raudsepp-Hearne C (2005) (eds.): Ecosystems and human well-being: multiscale assessments: findings of the Sub-global Assessments Working Group of the Millenium Ecosystem Assessment. The Millenium Ecosystem Assessment Series No.v. 4. Washington, D.C., USA, Island Press 388p. ISBN: 1-55963-186-4.

Cunningham AB (2001): Applied Ethnobotany: People, Wild Plant Use and Conservation. WWF. Earthscan Publications Ldt, London.

De Caluwé E, De Smedt S, Assogbadjo A, Samson E (2009): Ethnic differences in use value and use patterns of baobab (Adansonia digitata L.) in northern Benin. African J Ecol 47: 433-440.
Dressler S, Schmidt M, ZizKa G (2014): Introducing African Plants - A Photo Guide - An interactive photo database and rapid identification tool for continental Africa. Taxon 63: 1159-1164.

Heubach K, Wittig R, Nuppenau EA, Hahn K (2011): The economic importance of non-timber forest products (NTFPs) for livelihood maintenance of rural west African communities: a case study from northern Benin. Ecol Econ 70: 1991-2001.

Heubes J, Heubach K, Schmidt M, Wittig R, Zizka G, NupPENAU EA, Hahn K (2012): Impact of Future Climate and Land use Change on Non-timber Forest Product Provision in Benin, West Africa: Linking Niche-based Modelling with Ecosystem Service Values. Econ Bot 66: 383-397.

KePE T (2008): Beyond the numbers: Understanding the value of vegetation to rural livelihoods in Africa. Geoforum 39: 958-968.

LYKKE AM, KRISTENSEN MK, GANABA S (2004): Valuation of local use and dynamics of 56 woody species in the Sahel. Biodiversity Conservation 13: 1961-1990.

Paré S, Savadogo P, Tigabu M, Ouadba JM, Odén PC (2010): Consumptive values and local perception of dry forest decline in Burkina Faso, West Africa. Environment Developmen Sustainability 12:277-295.

PROTA (2010): Plant Resources of Tropical Africa. Promising African plants. A selection from the PROTA programme. PROTA Foundation, Wageningen, Netherlands / CTA, Wageningen, Netherlands. 169 pp.

Schmidt M, Janssen T, Dressler S, Hahn K, Hien M, Konaté S, Lykke AM, Mahamane A, Sambou B, Sinsin B, Thiombiano A, Wittig R \& G Zizka (2012): The West African Vegetation Database. In: Dengler J, Oldeland J, Jansen F, Chytrý M, Ewald J, Finckh M, Glöckler F, Lopez-Gonzalez G, Peet RK, Schaminée JHJ (Eds.): Vegetation databases for the 21st century. Biodiversity Ecol 4: 105-110. DOI: 10.7809/b-e.00065.

Schumann K, Wittig R, Thiombiano A, Becker U, Hahn K (2012): Uses, management, and population status of the baobab in eastern Burkina Faso. Agroforest Syst 85: 263278.

Sieglstetter R, Hahn K, Wittig R (2011): The use of woody species in northern Benin.- Flora Veg Sudano-Sambesica 14: 19-23.

Sop TK, Oldeland J, Bognounou O, Schmiedel U, ThIOMBIANO A (2012): Ethnobotanical knowledge and valuation of woody plants species: a comparative analysis of three ethnic groups from the sub-Sahel of Burkina Faso. Environment Developmen Sustainability DOI 10.1007/s10668-0129345-9.

Thiombiano A, Schmidt M, Dressler S, Ouédraogo A, HAHN K, ZizKA G (2012): Catalogue des plantes vasculaires du Burkina Faso. Boissiera 65. Conservatoire et jardin botaniques de la ville de Genève. $391 \mathrm{~S}$.

\section{E-mail adress: karen.hahn@bio-uni.frankfurt.de}

